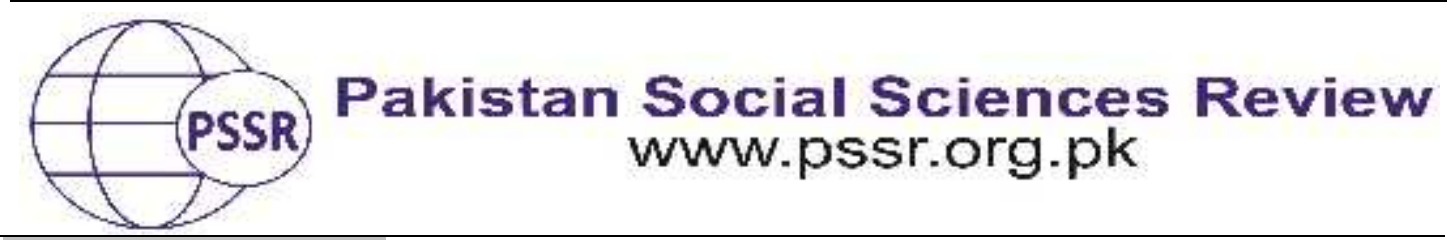

RESEARCH PAPER

\title{
Perceptions of Teachers on Prevalence of Sensory Problems among Children with Autism Spectrum Disorder
}

\author{
Tahmina Kausar ${ }^{1}$ Hina Fazil 2
}

1. M. Phil Scholar, Department of Education, University of Management and Technology, Lahore, Punjab, Pakistan

2. Assistant Professor, Department of Special Education, University of the Punjab, Lahore, Pakistan

\begin{tabular}{|c|c|}
\hline PAPER INFO & ABSTRACT \\
\hline $\begin{array}{l}\text { Received: } \\
\text { July 14, 2020 } \\
\text { Accepted: } \\
\text { September 05, } 2020 \\
\text { Online: } \\
\text { September 30, } 2020 \\
\text { Keywords: } \\
\text { Autism } \\
\text { Spectrum } \\
\text { Disorder, } \\
\text { Perception, } \\
\text { Sensory } \\
\text { Processing } \\
\text { Disorder } \\
\text { Corresponding } \\
\text { Author }\end{array}$ & $\begin{array}{l}\text { Sensory processing disorder is a complex neurobiological } \\
\text { process in which the sensory input either from the environment } \\
\text { or from one`s body is poorly detected or interpreted and often } \\
\text { unusual responses are obtained or sometimes no response is } \\
\text { made. Unfortunately, children with autism also show impaired, } \\
\text { repetitive, and restricted behaviors. The current study was } \\
\text { conducted to analyze such abnormalities among children with } \\
\text { autism. The questionnaire was made as a tool and data were } \\
\text { collected from teachers dealing with children affected by autism. } \\
\text { A sample of } 125 \text { teachers was selected from different public and } \\
\text { private sector schools of Lahore city for data collection. The data } \\
\text { were analyzed through SPSS software. Descriptive and } \\
\text { inferential statistics were applied to find the results of the study. } \\
\text { Independent sample t-test and correlation were run to reach the } \\
\text { results and the mean value was calculated. The results of the } \\
\text { study concluded that Vision is found to be the most common } \\
\text { sensory issue among all the children. Early interventions, } \\
\text { occupational and sensory therapies can be helpful to overcome } \\
\text { the sensory issues. }\end{array}$ \\
\hline
\end{tabular}

\section{Introduction}

The human brain is the most complex organ in our body. Even in the 21st century, we are toiling to grasp the complications that arise from little variations in gene structure leading to unexpected changes in brain function. Autism spectrum disorder or commonly referred to as ASD is one of those variations in brain function that has not yet been able to prevent or cure (Kuhlthau, Orlich, Hall, 2010). According to the American psychiatric association out of every fifty-nine children is suffering from autism spectrum disorder in one way or another which if one understands ASD would consider a terrifying number (APA, 2013). Boys are four 
times more likely to develop ASD compared to the girls. The individuals or children going through ASD face challenges on a broad range of aspects like social interaction, speech, non-verbal communication, comprehension, interpretation, and general behavior (Gov.NZ, 2016). The parameters, characteristics, and traits of autism are widely variable for each patient, which is why we use the word spectrum to identify it (Copeland, 2018).

Sensory processing is a composite of the neurobiological development process which is described by individuals' seven senses perceives info or stimuli from the atmosphere, transferring data to the central nervous system to interpret procedure and react (Baker, Angley \& Young, 2009). The senses and brains are continuously involved in a process of perceiving, understanding, processing, and reacting to environmental stimuli (Dunn, Saiter, \& Rinner, 2002). Sensory processing is a developmental procedure and therefore thought very fundamental in the children's first 10 years of life (Goodman-Scott \& Lambert, 2015). Researchers have estimated that SPD occurs in approximately $5-17 \%$ of children (Goodman-Scott \& Lambert, 2015). Sensory processing disorder has a significant impact on the whole life of a child (Walbam, 2014). Moreover, youngsters showing basic signs of the disorder, they frequently express a host of minor responsive and interactive complications consequently the syndrome, for instance, obstruction, isolation, low self-confidence, a larger possibility for anxious peer interactions, hindrance, and social, demonstrative and perform educational tasks (Withrow, 2007).

There are three major segments of sensory integration and those are tactile, vestibular, and proprioceptive (Foundation, 2014). Experts know that these three segments are the primary pillars of our sensory integration (Mangeot, et al., 2001). Subtypes of sensory processing disorder include; hypersensitive also known as under sensitive is the first type of sensory processing disorder and referred to as low level or reduced sensitivity of stimulus (Aben-Sasson, Carter, \& Briggs-Gowan, 2009). Hypersensitive also known as over-sensitive and is the second type of sensory processing disorder which is characterized by oversensitive towards a specific stimulus (Foundation, 2014). Human beings have different senses such as; sight/visual, hearing/auditory, smell/olfactory, taste/gustatory, touch/tactile, balance/vestibular, and body awareness/proprioception that fall under the category of sensory processing (Gourley, Carina Wind, \& Chinitz, 2013).

\section{Material and Methods}

\section{Research Design}

The researchers have selected a quantitative research design to investigate the prevalence of sensory problems among children with ASD. The nature of the study was the descriptive type. 


\section{Sample and Population of the Study}

The population of this study was teachers of children with ASD. The researchers have selected the sample from various private and government special schools in Lahore using a random sampling technique. The sample sized of 125 teachers was selected to investigate the prevalence of sensory issues among children with ASD.

\section{The Instrument of the Study}

The Questionnaire was prepared for this study was based on the instrument designed by the occupational therapist "Lindesy Biel". Researchers took her permission through email and some necessary amendments were made in the questionnaire according to the situation of teachers and schools in Lahore Pakistan. The questionnaire consisted of two segments, one dedicated to the demographic information and the other consisted of statements for sensory problems in children with ASD.

\section{Data Collection and Analysis}

Researchers have collected data personally by visiting the public and private schools in Lahore. Permission was taken from the school administration to collect data from the teachers and parents of the children with ASD After successful completion of data collection, the responses of the questionnaire were coded through a coding scheme and entered in SPSS software for analysis. Responses to each statement (such as $1=$ never, $2=$ often, $3=$ unsure, $4=$ sometimes, $5=$ yes frequently) of the questionnaire were tabulated, analyzed, and interpreted.

\section{Results and Discussion}

Table 1

Frequency Distribution of the Responses of Teachers on the Students with Autism Spectrum Disorder

\begin{tabular}{|c|c|c|c|c|c|c|c|c|c|c|c|}
\hline \multirow[t]{2}{*}{ Sr.\# } & \multirow[t]{2}{*}{ Questions } & \multicolumn{2}{|c|}{ Never } & \multicolumn{2}{|c|}{ Often } & \multicolumn{2}{|c|}{ Unsure } & \multicolumn{2}{|c|}{ Sometimes } & \multicolumn{2}{|c|}{$\begin{array}{c}\text { Yes, } \\
\text { Frequently }\end{array}$} \\
\hline & & f & $\%$ & $\mathbf{f}$ & $\%$ & $\mathbf{f}$ & $\%$ & f & $\%$ & $\mathbf{f}$ & $\%$ \\
\hline \multicolumn{12}{|c|}{ Tactile } \\
\hline 1 & $\begin{array}{l}\text { Do students avoid } \\
\text { casual touch from } \\
\text { teachers? }\end{array}$ & 49 & 39.2 & 14 & 11.2 & 9 & 7.2 & 36 & 28.8 & 17 & 13.6 \\
\hline 2 & $\begin{array}{c}\text { Do the students } \\
\text { become senseless } \\
\text { when touched? }\end{array}$ & 69 & 55.2 & 10 & 8.0 & 16 & 12.8 & 22 & 17.6 & 8 & 6.4 \\
\hline 3 & $\begin{array}{l}\text { Do the students } \\
\text { become upset by } \\
\text { the touch of hands, } \\
\text { clay, paints, sand, }\end{array}$ & 42 & 33.6 & 16 & 12.8 & 10 & 8.0 & 43 & 34.4 & 14 & 11.2 \\
\hline
\end{tabular}




\begin{tabular}{|c|c|c|c|c|c|c|c|c|c|c|c|}
\hline & $\begin{array}{c}\text { food, or any other } \\
\text { material? }\end{array}$ & & & & & & & & & & \\
\hline 4 & $\begin{array}{c}\text { Do they entail } \\
\text { various textures, } \\
\text { materials, paper, } \\
\text { and toys? }\end{array}$ & 29 & 23.2 & 25 & 20.0 & 19 & 15.2 & 36 & 28.8 & 16 & 12.8 \\
\hline 5 & $\begin{array}{l}\text { Do the students } \\
\text { become distressed } \\
\text { by certain } \\
\text { vibration: i.e. air } \\
\text { conditioners or } \\
\text { trucks? }\end{array}$ & 23 & 18.4 & 20 & 16.0 & 17 & 13.6 & 34 & 27.2 & 31 & 24.8 \\
\hline \multicolumn{12}{|c|}{ Vision } \\
\hline 6 & $\begin{array}{l}\text { Have they } \\
\text { difficulty with } \\
\text { handwriting? }\end{array}$ & 16 & 12.8 & 25 & 20.0 & 5 & 4.0 & 22 & 17.6 & 57 & 45.6 \\
\hline 7 & $\begin{array}{l}\text { They face difficulty } \\
\text { while copying } \\
\text { from the board. }\end{array}$ & 14 & 11.2 & 15 & 12.0 & 14 & 11.2 & 25 & 20.0 & 57 & 45.6 \\
\hline 8 & $\begin{array}{c}\text { They distracted by } \\
\text { brightly, shiny } \\
\text { light, and flaming } \\
\text { lighting }\end{array}$ & 25 & 20.0 & 20 & 16.0 & 14 & 11.2 & 29 & 23.2 & 37 & 29.6 \\
\hline 9 & $\begin{array}{c}\text { Have they poor } \\
\text { skills in catching } \\
\text { and throwing the } \\
\text { ball. }\end{array}$ & 25 & 20.0 & 18 & 14.4 & 11 & 8.8 & 25 & 20.0 & 46 & 36.8 \\
\hline 10 & $\begin{array}{l}\text { Do they make poor } \\
\text { eye contact with } \\
\text { others? }\end{array}$ & 22 & 17.6 & 17 & 13.6 & 3 & 2.4 & 40 & 32.0 & 43 & 34.4 \\
\hline \multicolumn{12}{|c|}{ Vestibular/Balance } \\
\hline 11 & $\begin{array}{c}\text { Do they } \\
\text { awkwardly move } \\
\text { their heads? }\end{array}$ & 40 & 32.0 & 19 & 15.2 & 7 & 5.6 & 22 & 17.6 & 37 & 29.6 \\
\hline 12 & $\begin{array}{l}\text { Do they fall on the } \\
\text { chair sits? }\end{array}$ & 68 & 54.4 & 14 & 11.2 & 5 & 4.0 & 22 & 17.6 & 16 & 12.8 \\
\hline 13 & $\begin{array}{l}\text { Do they need } \\
\text { support for floor } \\
\text { sitting? }\end{array}$ & 72 & 57.6 & 8 & 6.4 & 7 & 5.6 & 26 & 20.8 & 12 & 9.6 \\
\hline 14 & $\begin{array}{l}\text { Do they touch the } \\
\text { furniture or walls } \\
\text { while walking? }\end{array}$ & 47 & 37.6 & 8 & 6.4 & 5 & 4.0 & 34 & 27.2 & 31 & 24.8 \\
\hline 15 & $\begin{array}{l}\text { Do they hesitate } \\
\text { while moving in } \\
\text { the playground? }\end{array}$ & 35 & 28.0 & 18 & 14.4 & 5 & 4.0 & 35 & 28.0 & 32 & 25.6 \\
\hline 16 & $\begin{array}{c}\text { Do they get while } \\
\text { using upset }\end{array}$ & 35 & 28.0 & 13 & 10.4 & 11 & 8.8 & 43 & 34.4 & 23 & 18.4 \\
\hline
\end{tabular}


playground tools

e.g. -slides, swings, and ladders?

\begin{tabular}{|c|c|c|c|c|c|c|c|c|c|c|c|}
\hline \multicolumn{12}{|c|}{ Auditory } \\
\hline 17 & $\begin{array}{c}\text { i.e. singers and } \\
\text { musical } \\
\text { instruments? }\end{array}$ & 49 & 39.2 & 19 & 15.2 & 8 & 6.4 & 26 & 20.8 & 23 & 18.4 \\
\hline 18 & $\begin{array}{l}\text { Sometimes they } \\
\text { become upset in } \\
\text { gathering? }\end{array}$ & 13 & 10.4 & 24 & 19.2 & 11 & 8.8 & 44 & 35.2 & 33 & 26.4 \\
\hline 19 & $\begin{array}{c}\text { They learn more } \\
\text { easily in a one-to- } \\
\text { one situation than } \\
\text { in a team? }\end{array}$ & 11 & 8.8 & 8 & 6.4 & 8 & 6.4 & 26 & 20.8 & 72 & 57.6 \\
\hline \multicolumn{12}{|c|}{ Proprioception } \\
\hline 20 & $\begin{array}{c}\text { They don't know } \\
\text { where body parts } \\
\text { are? }\end{array}$ & 47 & 37.6 & 18 & 14.4 & 10 & 8.0 & 26 & 20.8 & 24 & 19.2 \\
\hline 21 & $\begin{array}{c}\text { Do they have poor } \\
\text { body awareness } \\
\text { about their } \\
\text { surroundings? }\end{array}$ & 38 & 30.4 & 27 & 21.6 & 9 & 7.2 & 24 & 19.2 & 27 & 21.6 \\
\hline 22 & $\begin{array}{l}\text { Do they crash with } \\
\text { furniture and } \\
\text { walls? }\end{array}$ & 49 & 39.2 & 12 & 9.6 & 12 & 9.6 & 31 & 24.8 & 21 & 16.8 \\
\hline 23 & $\begin{array}{l}\text { Students drop } \\
\text { items on the floor, } \\
\text { knock at doors } \\
\text { although not } \\
\text { angry? }\end{array}$ & 40 & 32.0 & 21 & 16.8 & 15 & 12.0 & 27 & 21.6 & 22 & 17.6 \\
\hline 24 & $\begin{array}{c}\text { Do they have face } \\
\text { problems in } \\
\text { sentence making? }\end{array}$ & 16 & 12.8 & 12 & 9.6 & 6 & 4.8 & 20 & 16.0 & 71 & 56.8 \\
\hline \multicolumn{12}{|c|}{ Smell and Taste } \\
\hline 25 & $\begin{array}{l}\text { Do they avoid } \\
\text { certain tastes? }\end{array}$ & 27 & 21.6 & 10 & 8.0 & 25 & 20.0 & 30 & 24.0 & 33 & 26.4 \\
\hline 26 & $\begin{array}{l}\text { Sometimes they } \\
\text { don't notice strong } \\
\text { smells about food? }\end{array}$ & 29 & 23.2 & 14 & 11.2 & 22 & 17.6 & 38 & 30.4 & 22 & 17.6 \\
\hline 27 & $\begin{array}{l}\text { Do they have an } \\
\text { imperfect diet? }\end{array}$ & 42 & 33.6 & 12 & 9.6 & 23 & 18.4 & 25 & 20.0 & 23 & 18.4 \\
\hline 28 & $\begin{array}{c}\text { They just act out in } \\
\text { the cafeteria? }\end{array}$ & 16 & 12.8 & 11 & 8.8 & 36 & 28.8 & 37 & 29.6 & 25 & 20.0 \\
\hline
\end{tabular}




\begin{tabular}{|c|c|c|c|c|c|c|c|c|c|c|c|}
\hline \multicolumn{12}{|c|}{ Behavior, Learning, and social issues } \\
\hline 29 & $\begin{array}{c}\text { They don't } \\
\text { understand the } \\
\text { concept of personal } \\
\text { space? }\end{array}$ & 14 & 11.2 & 23 & 18.4 & 17 & 13.6 & 31 & 24.8 & 39 & 31.2 \\
\hline 30 & $\begin{array}{c}\text { Do they face } \\
\text { difficulties in } \\
\text { joining group } \\
\text { activities? }\end{array}$ & 18 & 14.4 & 17 & 13.6 & 10 & 8.0 & 32 & 25.6 & 48 & 38.4 \\
\hline 31 & $\begin{array}{l}\text { Have they troubled } \\
\text { with transitions } \\
\text { between actions? }\end{array}$ & 10 & 8.0 & 22 & 17.6 & 20 & 16.0 & 34 & 27.2 & 39 & 31.2 \\
\hline 32 & $\begin{array}{l}\text { Do they face } \\
\text { problems in } \\
\text { completing tasks? }\end{array}$ & 13 & 10.4 & 24 & 19.2 & 10 & 8.0 & 36 & 28.8 & 42 & 33.6 \\
\hline 33 & $\begin{array}{l}\text { Did they become } \\
\text { easily unsatisfied? }\end{array}$ & 17 & 13.6 & 20 & 16.0 & 11 & 8.8 & 34 & 27.2 & 43 & 34.4 \\
\hline
\end{tabular}

Results of question 1 show that about $39.2 \%$ of teachers responded on never, $11.2 \%$ of respondents often, $7.2 \%$ of respondents were unsure, $28.8 \%$ respondents on sometimes while $13.6 \%$ of respondents were on yes, frequently. The point of view of the majority of the respondents was that students with ASD don't avoid casual touch from teachers. Results of question 2 show that about $55.2 \%$ of teachers responded on never, $8.0 \%$ of respondents often, $12.8 \%$ of respondents were unsure, $17.6 \%$ respondents on sometimes while, $6.4 \%$ of respondents were on yes, frequently. The point of view of the majority of the respondents was that students with ASD don't become senseless when touched. Results of question 3 show that about $33.6 \%$ of teachers responded on never, $12.8 \%$ of respondents often, $8.0 \%$ of respondents were unsure, $34.4 \%$ respondents with sometimes while, $11.2 \%$ of respondents with yes, frequently. The point of view of the majority of the respondents was that students with ASD sometimes upset by the touch of hands, clay, paints, sand, food, or any other material. Results of question 4 show that about $23.2 \%$ of teachers responded on never, $20.0 \%$ of respondents with often, $15.2 \%$ of respondents were unsure, $28.8 \%$ respondents on sometimes while, $12.8 \%$ of respondents were on yes, frequently. The point of view of the Majority of the respondents was that students with ASD sometimes want to play with the various textures, materials, paper, and toys. Results of question 5 show that about $18.4 \%$ of teachers responded on never, $16.0 \%$ of respondents with often, $13.6 \%$ of respondents were unsure, $27.2 \%$ of respondents with sometimes while, $24.8 \%$ of respondents with yes, frequently. The point of view of the majority of the respondents was that students with ASD sometimes upset by certain vibration: i.e. air conditioner or trucks.

Results of question 6 show that about $12.8 \%$ of teachers responded on never, $20.0 \%$ of respondents with often, $4.0 \%$ of respondents were unsure, $17.6 \%$ of respondents with sometimes while, $45.6 \%$ of 'respondents with yes, frequently. The 
point of view of the Majority of the respondents was that students with ASD frequently face difficulty in handwriting. Results of question 7 show that about $11.2 \%$ of teachers responded on never, $12.0 \%$ of respondents with often, $11.2 \%$ of respondents were unsure, $20.0 \%$ respondents with sometimes while, $45.6 \%$ of respondents with yes, frequently. The point of view of the majority of the respondents was that students with ASD frequently face difficulty while copying from the board. Results of question 8 show that about $20.0 \%$ of teachers responded on never, $16.0 \%$ of respondents often, $11.2 \%$ of respondents were unsure, $23.2 \%$ of respondents on sometimes while, $29.6 \%$ of respondents with yes, frequently. The point of view of the majority of the respondents was that students with ASD were frequently distracted by brightly, shiny light, and flaming lighting. Results of question 9 show that about $20.0 \%$ of teachers responded on never, $14.4 \%$ of respondents with often, $8.8 \%$ of respondents were unsure, $20.0 \%$ of respondents on sometimes while, $36.8 \%$ of respondents with yes, frequently. The point of view of the majority of the respondents was that students with ASD have poor skills in catching and throwing the ball. Results of question 10 show that about $17.6 \%$ of teachers responded with never, $13.6 \%$ of respondents with often, $2.4 \%$ of respondents were unsure, $32.0 \%$ respondents with sometimes while, $34.4 \%$ of respondents with yes, frequently. The point of view of the majority of the respondents was that students with ASD frequently have poor eye contact with peers

Results of question 11 show that about $32.0 \%$ of teachers responded on never, $15.2 \%$ of respondents with often, $5.6 \%$ of respondents were unsure, $17.6 \%$ of respondents on sometimes while, $29.6 \%$ of respondents with yes, frequently. The point of view of the majority of the respondents was that students with ASD don't awkwardly move their heads. Results of question 12 show that about $54.4 \%$ of teachers responded on never, $11.2 \%$ of respondents with often, $4.0 \%$ of respondents were unsure, $17.6 \%$ of respondents on sometimes while, $12.8 \%$ of respondents with yes, frequently. The point of view of the majority of the respondents was that students with ASD don't fall while sitting on the chair. Results of question 13 show that about $57.6 \%$ of teachers responded on never, $6.4 \%$ of respondents with often, $5.6 \%$ of respondents were unsure, $20.8 \%$ respondents with sometimes while, $9.6 \%$ of respondents with yes, frequently. The point of view of the majority of the respondents was that students with ASD don't need support for floor sitting. Results of question 14 show that about $37.6 \%$ of teachers responded on never, $6.4 \%$ of respondents with often, $4.0 \%$ of respondents were unsure, $27.2 \%$ of respondents with sometimes while, $24.8 \%$ of respondents were on yes, frequently. The point of view of the majority of the respondents was that students with ASD don't touch furniture or walls while walking. Results of question 15 show that about $28.0 \%$ of teachers responded on never, $14.4 \%$ of respondents with often, $4.0 \%$ of respondents were unsure, $28.0 \%$ of respondents on sometimes while, $25.6 \%$ of respondents with yes, frequently. The point of view of the majority of the respondents was that students with ASD don't hesitate while moving in the playground and according to the majority of the respondents sometimes feel hesitation while moving in the playground. Results of question 16 show that about $28.0 \%$ of teachers responded on 
never, $10.4 \%$ of respondents with often, $8.8 \%$ of respondents were unsure, $34.4 \%$ respondents with sometimes while, $18.4 \%$ of respondents with yes, frequently. The point of view of the Majority of the respondents was that students with ASD sometimes upset while using playground tools e.g. slides, swings, and ladders

Results of question 17 show that about $39.2 \%$ of teachers responded on never, $15.2 \%$ of respondents with often, $6.4 \%$ of respondents were unsure, $20.8 \%$ of respondents with sometimes while, $18.4 \%$ of respondents with yes, frequently. The point of view of the majority of the respondents was that students with ASD don't disturb certain sounds i.e. singers and musical instruments. Results of question 18 show that about $10.4 \%$ of teachers responded on never, $19.2 \%$ of respondents with often, $8.8 \%$ of respondents were unsure, $35.2 \%$ of respondents with sometimes while, $26.4 \%$ of respondents were with yes, frequently. The point of view of the majority of the respondents was that students with ASD sometimes become upset in gathering. Results of question 19 show that about $8.8 \%$ of teachers responded on never, $6.4 \%$ of respondents often, $6.4 \%$ of respondents were unsure, $20.8 \%$ of respondents with sometimes while, $57.6 \%$ of respondents with yes, frequently. The point of view of the majority of the respondents was that students with ASD frequently learn more easily in the one-to-one situation as compare to a team.

Results of question 20 show that about $37.6 \%$ of teachers responded on never, $14.4 \%$ of respondents with often, $8.0 \%$ of respondents were unsure, $20.8 \%$ of respondents on sometimes while, $19.2 \%$ of respondents were on yes, frequently. The point of view of the majority of the respondents was that students with ASD to know about their body parts. Results of question 21 show that about $30.4 \%$ of teachers responded on never, $21.6 \%$ of respondents with often, $7.2 \%$ of respondents were unsure, $19.2 \%$ respondents on sometimes while, $21.6 \%$ of respondents were with yes, frequently. The point of view of the majority of the respondents was that students with ASD have body awareness about their surroundings. Results of question 22 show that about $39.2 \%$ of teachers responded with never, $9.6 \%$ respondent with often, $9.6 \%$ of respondents were unsure, $24.8 \%$ of respondents on sometimes while, $16.8 \%$ of respondents with yes, frequently. The point of view of the majority of the respondents was that students with ASD don't bump with furniture and walls. Results of question 23 show that about $32.0 \%$ of teachers responded on never, $16.8 \%$ of respondents with often, $12.0 \%$ of respondents were unsure, $21.6 \%$ respondents with sometimes while, $17.6 \%$ of respondents with yes, frequently. The point of view of the majority of the respondents was that students with ASD don't drop items on the floor, knock at doors although not angry. Results of question 24 show that about $12.8 \%$ of teachers responded on never, $9.6 \%$ of respondents with often, $4.8 \%$ of respondents were unsure, $16.0 \%$ of respondents with sometimes while, $56.8 \%$ of respondents with yes, frequently. The point of view of the majority of the respondents was that students with ASD frequently face problems in sentence making. 
Results of question 25 show that about $21.6 \%$ of teachers responded on never, $8.0 \%$ of respondents with often, $20.0 \%$ of respondents were unsure, $24.0 \%$ of respondents on sometimes while, $26.4 \%$ of respondents with yes, frequently. The point of view of the Majority of the respondents was that students with ASD usually avoid a certain taste. Results of question 26 show that about $23.2 \%$ of teachers responded with never, $11.2 \%$ of respondents with often, $17.6 \%$ of respondents were unsure, $30.4 \%$ of respondents on sometimes while, $17.6 \%$ of respondents with yes, frequently. The point of view of the majority of the respondents was that students with ASD Sometimes note their food smell. Results of question 27 show that about $33.6 \%$ of teachers responded with never, $9.6 \%$ of respondents with often, $18.4 \%$ of respondents were unsure, $20.0 \%$ of respondents with sometimes while, $18.4 \%$ of respondents with yes, frequently. The point of view of the majority of the respondents was that students with ASD have a perfect diet. Results of question 28 show that about $12.8 \%$ of teachers responded on never, $8.8 \%$ of respondents with often, $28.8 \%$ of respondents were unsure, $29.6 \%$ of respondents with sometimes while, $20.0 \%$ of respondents with yes, frequently. The point of view of the majority of the respondents was that students with ASD sometimes act out in the cafeteria.

Results of question 29 show that about $11.2 \%$ of teachers responded with never, $18.4 \%$ of respondents with often, $13.6 \%$ of respondents were unsure, $24.8 \%$ respondents with sometimes while, $31.2 \%$ of respondents with yes, frequently. The point of view of the majority of the respondents was that students with ASD usually understand the concept of personal space. Results of question 30 show that about $14.4 \%$ of teachers responded on never, $13.6 \%$ of respondents with often, $8.0 \%$ of respondents were unsure, $25.6 \%$ respondents with sometimes while, $38.4 \%$ of respondents with yes, frequently. The point of view of the majority of the respondents was that students with ASD frequently face difficulties in joining group activities. Results of question 31 show that about $8.0 \%$ of teachers responded with never, $17.6 \%$ of respondents with often, $16.0 \%$ of respondents were unsure, $27.2 \%$ of respondents with sometimes while, $31.2 \%$ of respondents with yes, frequently. The point of view of the majority of the respondents was that students with ASD frequently face trouble with transitions between actions. Results of question 32 show that about $10.4 \%$ of teachers responded on never, $19.2 \%$ of respondents often, $8.0 \%$ of respondents were unsure, $28.8 \%$ of respondents on sometimes while, $33.6 \%$ of respondents were on yes, frequently. The point of view of the majority of the respondents was that students with ASD frequently face problems in completing tasks. Results of question 33 show that about $13.6 \%$ of teachers responded on never, $16.0 \%$ of respondents with often, $8.8 \%$ of respondents were unsure, $27.2 \%$ of respondents on sometimes while, $34.4 \%$ of respondents were on yes, frequently. The point of view of the majority of the respondents was that students with ASD frequently come to be easily unsatisfied. 
Table 2

Independent sample t-test for tactile sensory issues based on gender

\begin{tabular}{lcrlllll}
\hline Test variable & Gender of The Child & N & Mean & S.D & $\mathbf{t}$ & df & Sig. \\
\hline $\begin{array}{c}\text { The total score of } \\
\text { tactile }\end{array}$ & Male & 99 & 17.9192 & 7.01264 & & \\
\hline & Female & 26 & 19.7692 & 7.07846 & -1.195123 & .234 \\
\hline
\end{tabular}

The significance and the mean value is $(t=-1.195, \mathrm{df}=123, \operatorname{sig}=.234$, Mean male=17.9192, Mean female=19.7692) show that there are no significant difference problems faced by male and female students with ASD about the tactile sensory issues.

Table 3

Independent sample t-test for visual sensory issues based on gender

\begin{tabular}{cccccccc}
\hline Test variable & Gender of the Child & N & Mean & S.D & $\mathbf{t}$ & $\mathbf{d f}$ & Sig. \\
\hline $\begin{array}{c}\text { The total score } \\
\text { of vision }\end{array}$ & Male & 99 & 28.4545 & 11.01694 & -.679 & 123 & .498 \\
\hline
\end{tabular}

The significance and the mean value $(\mathrm{t}=-.679, \mathrm{df}=123$, sig=.498, Mean male=28.4545, Mean female=30.0385). show that there are no significant difference problems faced by male and female students with ASD about the visual sensory issues.

Table 4

Independent sample t-test for vestibular issues based on gender

\begin{tabular}{cccccccr}
\hline Test variable & Gender of the child & $\mathbf{N}$ & Mean & S.D & $\mathbf{t}$ & df & Sig. \\
\hline $\begin{array}{c}\text { The total score of } \\
\text { vestibular }\end{array}$ & Male & 99 & 16.0101 & 5.53375 & \multirow{2}{*}{.558123} & \multirow{2}{*}{.578} \\
\hline
\end{tabular}

The significance and the mean value $(t=.558, \mathrm{df}=123$, sig=.578, Mean male=16.0101, Mean female=15.3077) show that there is no significant difference in problems faced by male and female students with ASD disorder about the vestibular sensory issues.

Table 5

Independent sample t-test for auditory issues based on gender

\begin{tabular}{|c|c|c|c|c|c|c|c|}
\hline Test variable & Gender of the child & $\mathbf{N}$ & Mean & S.D & $\mathbf{t}$ & df & Sig. \\
\hline The total score & Male & 99 & 19.4444 & 6.19450 & 208 & 123 & 836 \\
\hline of auditory & Female & 26 & 19.7308 & 6.46565 & & 120 & 030 \\
\hline
\end{tabular}

The significance and the mean value $(\mathrm{t}=-.208, \mathrm{df}=123, \mathrm{sig}=.836$, Mean male=19.4444, Mean female=19.46565) show that there are no significant difference problems faced by male and female students with ASD about the auditory sensory issues. 
Table 6

Independent sample t-testfor proprioception issues based on gender

\begin{tabular}{ccccccccc}
\hline Test variable & Gender of the child & $\mathbf{N}$ & Mean & S.D & t & df & Sig \\
\hline $\begin{array}{c}\text { The total score of } \\
\text { proprioception }\end{array}$ & Male & 99 & 19.6566 & 7.67737 & -.397 & .692 \\
\hline
\end{tabular}

The significance and the mean value $(t=-.397, d f=123$, sig=.692, Mean male=19.6566, Mean female=20.3846) show thatthere are no significant difference problems faced by male and female students with ASD about the proprioception sensory issues.

Table 7

Independent sample t-test for smell and taste problems based on gender

\begin{tabular}{cccccccc}
\hline Test variable & Gender of the Child & $\mathbf{N}$ & Mean & S.D & $\mathbf{t}$ & df & Sig. \\
\hline $\begin{array}{c}\text { The total score of } \\
\text { smell and taste }\end{array}$ & $\begin{array}{c}\text { Male } \\
\text { Female }\end{array}$ & 99 & 14.4141 & 5.31461 & .26 & 123 & .783 \\
\hline
\end{tabular}

The mean and the significant value $(\mathrm{t}=.276, \mathrm{df}=123$, sig=.783, Mean male=14.4141, Mean female=14.0769) show that there are no significant difference problems faced by male and female students with ASD about the smell and taste of sensory problems.

Table 8

Independent sample t-test for behavior learning and social issues based on gender

\begin{tabular}{|c|c|c|c|c|c|c|c|}
\hline Test & Gender of the child & $\mathbf{N}$ & Mean & S.D & $\mathbf{t}$ & df & Sig. \\
\hline $\begin{array}{l}\text { The tc } \\
\text { of } B I\end{array}$ & $\begin{array}{c}\text { Male } \\
\text { Female }\end{array}$ & $\begin{array}{l}99 \\
26\end{array}$ & $\begin{array}{l}17.9293 \\
18.5385\end{array}$ & $\begin{array}{l}5.28620 \\
4.97378\end{array}$ & -.529 & 123 & .598 \\
\hline
\end{tabular}

The significance and the mean value $(t=-.529, \mathrm{df}=123$, sig=.598, Mean male= 17.9293, Mean female=18.5385.) show that there are no significant differences in problems faced by male and female students with ASD about behavior, learning, and social issues.

Table 9

Independent sample t-test for tactile issues based on gender

\begin{tabular}{cccccccc}
\hline Test variable & $\begin{array}{c}\text { Gender of the } \\
\text { teachers }\end{array}$ & $\mathbf{N}$ & Mean & S.D & $\mathbf{t}$ & df & Sig. \\
\hline $\begin{array}{c}\text { The total score } \\
\text { of tactile }\end{array}$ & $\begin{array}{c}\text { Male } \\
\text { Female }\end{array}$ & 15 & 16.8667 & 5.05494 & -1.789123 & .076 \\
\hline
\end{tabular}

The significance and the mean value $(t=-1.789, \mathrm{df}=123$, sig $=.076$, Mean male $=16.8667$, Mean female 19.8909 ) show that there is no significant difference in the 
perception of male and female teachers about the tactile sensory problems of their students with ASD.

Table 10

Independent sample t-test for visual sensory issues based on the gender of teachers

\begin{tabular}{ccccccrr}
\hline Test variable & Gender of the teachers & $\mathbf{N}$ & Mean & S.D & $\mathbf{t}$ & df & Sig. \\
\hline $\begin{array}{c}\text { The total score of } \\
\text { vision }\end{array}$ & Male & 15 & 25.3333 & 6.13732 & .506 & 123 & .614 \\
\hline
\end{tabular}

The significance and the mean value is $(\mathrm{t}=.506, \mathrm{df}=123$, sig $=.614$, Mean male= 25.3333, Mean female= 24.3091) show that there is no significant difference in the perception of male and female teachers about the visual sensory problems of their students with ASD.

Table 11

Independent sample t-test for vestibular sensory issues based on gender of teachers

\begin{tabular}{cccccccc}
\hline Test variable & $\begin{array}{c}\text { Gender of the } \\
\text { teachers }\end{array}$ & $\mathbf{N}$ & Mean & S.D & $\mathbf{t}$ & df & Sig \\
\hline $\begin{array}{c}\text { The total score } \\
\text { of vestibular }\end{array}$ & $\begin{array}{c}\text { Male } \\
\text { Female }\end{array}$ & 15 & 17.9333 & 6.13732 & -1.198123 & .233 \\
\hline
\end{tabular}

The significance and the mean value $(t=-1.198, \mathrm{df}=123$, sig $=.233$, Mean male= 17.9333, Mean female $=20.1364$ ) show that there is no significant difference in the perception of male and female teachers about the vestibular sensory problems of their students with ASD.

Table 12

Independent sample t-test for auditory issues based on the gender of teachers

\begin{tabular}{|c|c|c|c|c|c|c|c|}
\hline Test variable & $\begin{array}{c}\text { Gender of the } \\
\text { teachers }\end{array}$ & $\mathbf{N}$ & Mean & S.D & $\mathbf{t}$ & df & Sig. \\
\hline $\begin{array}{c}\text { The total score of } \\
\text { auditory }\end{array}$ & $\begin{array}{c}\text { Male } \\
\text { Female }\end{array}$ & $\begin{array}{c}15 \\
110\end{array}$ & $\begin{array}{l}15.9333 \\
16.5000\end{array}$ & $\begin{array}{l}3.41147 \\
4.71723\end{array}$ & -.449 & 123 & .654 \\
\hline
\end{tabular}

The significance and the mean value $(t=-.449, \mathrm{df}=123$, sig $=.654$, Mean male $=$ 15.9333, Mean female= 16.5000) show that there is no significant difference in the perception of male and female teachers about the auditory sensory problems of their students with ASD.

Table 13

Independent sample t-test for the perception of teachers for proprioception sensory issues based on gender

\begin{tabular}{cccccccc}
\hline Test variable & $\begin{array}{c}\text { Gender of the } \\
\text { teachers }\end{array}$ & $\mathbf{N}$ & Mean & S.D & $\mathbf{t}$ & df & Sig. \\
\hline $\begin{array}{c}\text { The total score of } \\
\text { proprioception }\end{array}$ & $\begin{array}{c}\text { Male } \\
\text { Female }\end{array}$ & 15 & 21.0000 & 5.25085 & -.518 & 605 \\
\hline
\end{tabular}


The significance and the mean value $(t=-.518, \mathrm{df}=123$, sig $=.605$, Mean male $=$ 21.0000, Mean female= 22.0000) show that there is no significant difference in the perception of male and female teachers about the proprioception sensory problems of their students with ASD.

Table 14

Independent sample t-test for perception of teachers for smell and taste issues based on gender

\begin{tabular}{|c|c|c|c|c|c|c|}
\hline Test variable & $\begin{array}{l}\text { Gender of the } \\
\text { teachers }\end{array}$ & $\mathbf{N}$ & Mean & S.D & df & Sig. \\
\hline $\begin{array}{l}\text { The total score } \\
\text { of smell and } \\
\text { taste }\end{array}$ & $\begin{array}{l}\text { Male } \\
\text { Female }\end{array}$ & $\begin{array}{c}15 \\
110\end{array}$ & $\begin{array}{l}11.0000 \\
12.6909\end{array}$ & $\begin{array}{l}3.42261 \\
3.95791\end{array}$ & -1.575123 & .118 \\
\hline
\end{tabular}

The significance and the mean value $(\mathrm{t}=-1.575, \mathrm{df}=123$, sig $=.118$, Mean male= 11.0000, Mean female 12.6909 ) show that there is no significant difference in the perception of male and female teachers about the smell and taste of sensory problems of their students with ASD.

Table 15

Independent sample t-test for perception of teachers for behavior learning and social issues based on gender

\begin{tabular}{|c|c|c|c|c|c|c|c|}
\hline Test variable & $\begin{array}{l}\text { Gender of the } \\
\text { teachers }\end{array}$ & $\mathbf{N}$ & Mean & S.D & $\mathbf{t}$ & df & Sig \\
\hline $\begin{array}{l}\text { The total score } \\
\text { of BL and SI }\end{array}$ & $\begin{array}{c}\text { Male } \\
\text { Female }\end{array}$ & $\begin{array}{c}15 \\
110\end{array}$ & $\begin{array}{l}18.6000 \\
21.8727\end{array}$ & $\begin{array}{l}5.61630 \\
6.17499\end{array}$ & -1.945 & 123 & .054 \\
\hline
\end{tabular}

The significance and the mean value $(t=-1.945, d f=123$, sig $=.054$, Mean male $=18.6000$, Mean female= 21.8727) show that there is no significant difference in the perception of male and female teachers about the behavior learning and social issues of their students with ASD.

Table 16

Mean values for most common sensory issues

\begin{tabular}{ccc}
\hline Sr.\# & Statements & Mean \\
\hline 1 & Total score tactile & 18.3040 \\
\hline 2 & Total score vision & 28.7840 \\
\hline 3 & Total score vestibular & 15.8640 \\
\hline 4 & Total score auditory & 19.5040 \\
\hline 5 & Total score proprioception & 19.8080 \\
\hline 6 & The total score of smell and taste & 14.3440 \\
\hline 7 & Total score BL and SI & 18.0560
\end{tabular}


Table 15 depicts the highest mean of the sensory issues were of vision $(M=28.7840)$ than problems of Proprioception $(M=19.8080)$ than the problem of auditory $(M=19.5040)$ than the problem of tactile $(M=18.3040)$ than the problem of Behavioral, learning, and social issues $(\mathrm{M}=18.0560)$ than the problem of vestibular $(M=15.8640)$ and then the problem of Smell and taste $(M=14.3440)$.

\section{Discussion}

Until now only a few studies had evaluated the prevalence of sensory problems among children with ASD in Pakistan. Although, numerous studies had been conducted in European countries to evaluate sensory problems among children with ASD. A range of sensory problems (hypersensitive to hypersensitive) had been reported among children of mild to severe autism. Hirstein et al., (2001) described sensory problems of hypo and hypersensitivity that may coexist in autistic children. Likewise, the results of this study showed that according to the perception of teachers, children with ASD have a lot of sensory problems. Vision sensitivity was observed as the most common sensory issue among children with ASD. A strong correlation was observed among the point of view of male and female teachers about the sensory difficulties faced by the children with ASD. Such children have usually poor handwriting and usually don't avoid casual touch by their fellows, parents, teachers, and siblings. Similarly, another study by Leekam et al., (2007) indicates that sensory problems were more common in children with autism. At least $90 \%$ of children with ASD in both study 1 and study 2 had sensory issues. It was also stated that sensory impairments among children with ASD are persistent regardless of age and mental capability. Results of the present study proved that the most common sensory issues among the children with autism are vision, followed by proprioception and auditory problems, this finding is following the results of Wiggins, Robins, Bakeman, \& Adamson (2009), who found that about $90 \%$ of the children with autism had sensory difficulties in several domains. It has been also observed in the current study that sensory issues are equally found among male and female children.

\section{Conclusion}

Based on results, it can be concluded that children with autism have several sensory issues and autism is more common in males as compared to females. Vision sensitivity was found as the most common issue. It is also observed that children with autism sometimes show tactile issues. Some of the respondents also reported that children with ASD don't have issues when casually touched by parents, teachers, peers, and siblings. The results of the independent sample t-test proved that in the perception of teachers the sensory problems are prevalent in children with ASD. 


\section{Recommendations} made:

Based on the results of the study, the following recommendations were

- Sensory activities can be helpful to reduce sensory abnormalities among children with ASD.

- Interventions and sensory therapies also can be helpful to overcome sensory problems.

- Creating the sensory profile can be helpful for teachers and parents to work out what changes are required to overcome the sensory abnormalities.

- Visual supports can be helpful to manage behavior, learning, and social issues. 


\section{References}

Aben-Sasson, Carter, A., \& Briggs-Gowan, M. (2009). Sensory over-responsivity in elementary school: Prevalence and social-emotional correlates. Journal of Abnormal Child Psychology, 705-716. doi:10.1007/s10802-008-9295-8

APA. (2013). American Psychological Association (APA), Diagnostic and Statistical Manual of Mental Disorders-Text Revision. Washington, DC, USA: American Psychological Association (APA).

Caroline Whyatt, Cathy Craig. (2013). Sensory-motor problems in Autism.Journal of Frontiers in Negative Neuroscience, 7(51), NCBI: https://www.ncbi.nlm.nih.gov/pmc/articles/PMC3714545/

Copeland, J. N. (2018, August). What is Autism Spectrum Disorder.American Psychiatric Association. https://www.psychiatry.org/: https://www.psychiatry. org/patients-families/autism/what-is-autism-spectrum-disorder

Dunn, W., Saiter, J., \& Rinner, L. (2002). Asperger syndrome and sensory processing: A conceptual model and guidance for intervention planning. Focus on Autism and other Developmental Disabilities, 17(3), 172-185.

Foundation, S. (2014). SPD scientific work group. Sensory Processing Disorder Foundation. http://www.spdfoundation/net/collaborations.html, SPD Research Collaborations

Goodman-Scott, E., \& Lambert, S. F. (2015). Professional Counseling for Children With Sensory Processing Disorde. Counseling \& Human Services Faculty Publications. 12.

Goodman-scott, E., \& Lambert, S. F. (2015). Professional counseling for children with sensory processing disorder. The Professional Counselor, 5(2), 273-292.

Gourley, L., Carina Wind, E. M., \& Chinitz, S. (2013). Sensory Processing Difficulties, Behavioral Problems, and Parental Stress in a Clinical Population of Young Children. J Child Fam Stud, 22(3), 912-921.

Gov.NZ. (2016). Autism Spectrum Disorder Guideline. Wellington, New Zealand: Ministry of Health and Education, NZ.Retrieved from https://www.health.govt.nz/system/files/documents/publications/nz-asdguideline-aug16v2_0.pdf

Hatch-Rasmussen, C. (2018). Sensory Integration. Autism Research Institute. https://www.autism.com/symptoms_sensory_overview. 
Hirstein, W., Iversen, P., \& Ramachandran, V. S. (2001). Autonomic responses of autistic children to people and objects. Proceedings of the Royal Society B: Biological Sciences, 268(1479), 1883-8.

Kuhlthau, K., \& F Orlich, T. H. (2010). Health-Related Quality of Life in children with autism spectrum disorders: results from the autism treatment network. Journal of autism and developmental disorders, 40(6), 721-729.

Leekam, S. R., Nieto, C., Libby, S., \& Wing, L. (2007). Describing the Sensory Abnormalities of Children and Adults with Autism. Journal of Autism and Developmental Disorders, 37(5), 894-910.

Mangeot, S., Miller, I., McIntosh, D. N., McGrath-Clarke, J., Simon, J., Hagerman, R., \& Goldson, E. (2001). Sensory modulation dysfunction in children with attention de cit hyperactivity disorder. Journal ofDevelopmental Medicine and Child Neurology, 43, 399-406.

Ministries of Health and Education, Wellington, New Zealand. (2016, August 19). New Zealand Autism Spectrum Disorder Guideline. https://www.health.govt.nz /publication/new-zealand-autism-spectrum-disorder-guideline, Ministry of Health and Education,NZ

Miriam Liss, Celine Saulnier, Celine Saulnier, Marcel Kinsbourne. (2006). Sensory and attention abnormalities in autistic spectrum disorders.Autism, 10(2), 155-172. https://journals.sagepub.com/doi/abs/10.1177/1362361306062021

Myles, S., K.T Cook, N. M., Rinner, L., \& Robbins, L. A. (2005). Asperger Syndrome and Sensory Issues. Practical solutions for making sense of the world. Autism Asperger Publishing Co.

Roy Benaroch, M. (2016, November 19). What Are the Types of Autism Spectrum Disorders?https://www.webmd.com/brain/autism/autism-spectrum-disorders,

Walbam, K. (2014). The relevance of sensory processing disorder to social work practice: An interdisciplinary approach. Child and Adolescent Social Work Journal, 31, 61-70. doi:10.1007/s10560-013-0308-2

Wiggins, L., Robins, D., Bakeman, R., \& Adamson, L. (2009). Brief report: sensory abnormalities as distinguishing symptoms of autism spectrum disorders in young children. Journal of Autism and Developmental Disorders, 39(7), 1087-91.

Withrow, R. (2007). Sensory integration dysfunction: Implications for counselors working with children. Journal of School Counseling, 5(18), 1-24. 